\title{
Tube-building Amphipoda
}

\section{S.I. Smith}

To cite this article: S.I. Smith (1874) Tube-building Amphipoda, Annals and Magazine of Natural History, 14:81, 240-240, DOI: 10.1080/00222937408680961

To link to this article: http://dx.doi.org/10.1080/00222937408680961

$$
\text { 曲 Published online: } 15 \text { Oct } 2009 .
$$

Submit your article to this journal 준

LII Article views: 4

Q View related articles $₫$ 
paper referred to. The polymorphic forms of I. Ajax do not conform to the law of substance-waste. Perhaps Mr. Scudder, who has ample opportunities of studying this interesting species, may be induced to turn his attention to the subject and attack it experimentally.

August 3, 1874.

Tube-building Amphipoda. By S. I. Sмrтн.

In examining recently an alcoholic specimen of a species of $X_{t}-$ noclea, I noticed a peculiar opaque glandular structure filling a large portion of the third and fourth pairs of thoracie legs, which in most, if not all, the non-tubebuilding Amphipoda are wholly occupied by muscles. A further examination shows that the terminal segment (dactyias) in these legs is not acute and claw-like, but truncated at the tip and apparently tubular. In this species, a large cylindrical portion of the gland lies along each side of the long basal segment, and these two portions uniting at the distal end pass through the ischial and along the posterior side of the meral and carpal segments and doubtless connect with the tubular dactylus. There can be no doubt that these are the glands which secrete the cement with which the tubes are built, and that these two pairs of legs are specialized for that purpose.

A hasty examination revealed a similar structure of the corresponding legs in Amphithoë maculata, Ptilocheirus pinguis, Cerapus rubricornis, Byblis Gaimardi, and a species of Ampelisea. In all these except the last two a very large proportion of the gland is in the basal segment. In the Amphithoë this segment is thickened and the gland is in the middle. In the Cerapus it is very broad and almost entirely filled by the gland, with only very slender muscles through the middle, and the orifice in the dactylus is not at the very tip, but subterminal on the posterior side. In the Ptilocheirus the gland forms three longitudinal masses in the basal segment and is also largely developed in the meral and carpal segments. The dactylus is long and slender, and the orifice subterminal. In Ampelisca and Byblis (which, like Haploöps, are tube-building genera) the meral segments of the specialized legs are nearly as large as the basal, and contain a proportionally large part of the gland. In these genera the remarkable elongation of the two distal segments in the third and fourth pairs of legs is perhaps a special adaptation to enable them to reach back over the deep epimera.

The examination of fresh specimens will doubtless show these structures much more fully. - Silliman's American Journal, June 1874. 